\title{
FACTORS ASSOCIATED WITH THE BURNOUT SYNDROME AMONG PROFESSIONALS IN PHARMACEUTICAL MANUFACTURING INDUSTRY AND MARKETING 1234
}

\author{
Vesna R. Jovanović ${ }^{\text {, Dušanka Krajnović }}{ }^{\text {, }}$ \\ Goran Mihajlović ${ }^{3}$, Valentina Marinković ${ }^{4}$ \\ ${ }^{1}$ High medical school of the professional studies, Belgrade \\ 2 The center for the bioethical studies, University in Belgrade \\ ${ }^{3}$ Psychiatry Clinic, Clinical Center of Kragujevac \\ ${ }^{4}$ Faculty of Pharmacy, University of Belgrade
}

\section{ФАКТОРИ ПОВЕЗАНИ СА СИНДРОМОМ ИЗГАРАҢА КОД ПРОФЕСИОНАЛАЦА У ФАРМАЦЕУТСКОЈ ИНДУСТРИЈИ И МАРКЕТИНГУ}

\author{
Весна Р. Јовановић ${ }^{1}$, Душанка Крајновић ${ }^{2}$, \\ Горан Михајловић ${ }^{3}$, Валентина Маринковић ${ }^{4}$ \\ ${ }^{1}$ Висока здравствена школа струковних студија, Београд \\ 2 Центар за биоетичке студије, Универзитет у Београду \\ ${ }^{3}$ Клиника за психијатрију, Клинички центар Крагујевац \\ ${ }^{4}$ Фармацеутски фракултет, Универзитет у Београду
}

\section{СКРАЋЕНИЦЕ} ција)

DP - Depersonalization (Деперсонализа-

EE - Emotional exhaustion (Емоционална исцрпљеност)

MBI-HSS - Maslach Burnout Inventory (Маслачев упитник самопроцене синдрома изгарања)

PA - Personal accomplishment (Лично постигнуће)

RAS - The Rathus Assertiveness Schedule (Ратусова скала асертивности)

Abbreviations:

DP - Depersonalization

EE - Emotional exhaustion
MBI-HSS - Maslach Burnout Inventory Human Services Survey

PA - Personal accomplishment

RAS - The Rathus Assertiveness Schedule

\section{САЖЕТАК}

Поједини аутори наводе да су неке професије у области здравствене делатности подложније развоју синдрома изгарања, док други сугеришу да карактеристике самог посла нису најзначајнији узрочници изгарања на раду, већ да примарну улогу у његовом настанку имају психосоцијални аспекти радног места.

Основни циљ истраживања био је да се испита који су фактори повезани са синдромом изгарања код запослених у фармацеут-

Контакт: Весна Р. Јовановић

Висока здравствена школа струковних студија, Београд

e-mail: vesnajovanovic07@gmail.com 
ској индустрији и маркетингу. Ово истраживање је спроведено током јуна 2016. године као студија пресека и обухватило је 75 високообразованих професионалаца из домена фармацеутске индустрије и маркетинга, запослених у неколико домаћих и реномираних међународних фармацеутских компанија са територије Београда. Анкетирање је било анонимно. Као инструменти истраживања коришћени су општи социодемографски упитник, упитник за самопроцену нивоа асертивности и Маслач инвентар изгарања (енг. Маslach Burnout Inventory).

Анализа одговора из упитника за самопроцену синдрома изгарања показала је да се највиши степен изгарања испољава у димензији умањеног личног постигнућа 53\%. Просечне вредности асертивности биле су најмање код особа са највишим нивоом емоционалне исцрпљености $(\mathrm{p}=0,003)$, деперсонализације $(\mathrm{p}=0,004)$ и највишим нивоом неефикасности на скали професионалног постигнућа $(\mathrm{p}=0,001)$. Статистички значајна разлика пронађена је у заступљености и изражености емоционалне исцрпљености у односу на пол испитаника $(\chi 2=10,779 ; p<0,05)$ и област рада $(\chi 2=6,493 ; \mathrm{p}<0,05)$. На израженост деперсонализације утичу област рада $(\chi 2=5,393$; $\mathrm{p}<0,05)$, године старости $(\mathrm{p}=0,004)$, укупан радни стаж $(\mathrm{p}=0,009)$ и радни стаж у струци $(\mathrm{p}=0,006)$. На осећај умањеног личног постигнућа битно утичу професија $(\chi 2=10,922$; $\mathrm{p}<0,05)$ и област рада $(\chi 2=7,283 ; \mathrm{p}<0,05)$. Добијени резултати могли би помоћи у идентификацији ризичних група за развој синдрома изгарања међу професионалцима из домена фармацеутске индустрије и маркетинга, као и бољем сагледавању значаја интерперсоналног функционисања запослених у циљу планирања превентивних мера.

Кључне речи: синдром изгарања, асертивност, фармацеутска индустрија и маркетинг.

\section{ABSTRACT}

Certain authors describe some professions in the healthcare industry as the more susceptible ones to developing a burnout syndrome, while others suggest psychosocial aspects of the workplace as the primary cause in its creation, but not the aspects of the job itself.

The main objective of the research was to investigate which specific factors were associated with the burnout syndrome among professionals working in pharmaceutical manufacturing industry and marketing.
The study was conducted in June of 2016 as a cross-sectional study and it included 75 university educated professionals from the area of pharmaceutical industry and marketing employed in several local as well as internationally renowned pharmaceutical companies located in Belgrade. The participants were surveyed anonymously. The instruments used in the study were: a general socio-demographic questionnaire, an assertiveness self-evaluation questionnaire and the Maslach Burnout Inventory.

An analysis of the responses in the burnout syndrome self-evaluation questionnaires showed that the highest level of burnout was expressed through reduced personal accomplishment $(53 \%)$. The average assertiveness scores were the lowest in the individuals who demonstrated the highest level of emotional exhaustion $(\mathrm{p}=0.003)$, depersonalization $(\mathrm{p}=0.004)$, and the highest inefficiency on professional accomplishment scale $(\mathrm{p}=0.001)$. A statistically significant difference was observed in frequency and extent of emotional exhaustion with respect to respondents' gender $(\chi 2=10.779 ; \mathrm{p}<0.05)$, as well as the line of business $(\chi 2=6.493 ; \mathrm{p}<0.05)$. Levels of depersonalization are influenced by: line of work $(\chi 2=5.393 ; p<0.05)$, age $(\mathrm{p}=0.004)$, total years of service $(\mathrm{p}=0.009)$ and years of service in the profession $(\mathrm{p}=0.006)$. A sense of reduced personal accomplishment is influenced by a respondents' profession $(\chi 2=10.922$; $\mathrm{p}<0.05)$ and line of business $(\chi 2=7.283 ; \mathrm{p}<0.05)$. The results obtained in this study might help in identifying groups at risk for developing the burnout among the pharmaceutical manufacturing industry and drug marketing professionals. They might also assist in better assessing of the significance of interpersonal interactions between the employees for the purpose of planning the measures for the burnout prevention.

Keywords: burnout syndrome, assertiveness, pharmaceutical manufacturing industry and drug marketing.

\section{INTRODUCTION}

In contemporary pharmaceutical practice, which is focused on improving safety, therapy outcomes and patients quality of life, pharmacists can face the burnout syndrome and an increased work-related stress ${ }^{1}$.

The burnout syndrome in the pharmaceutical profession can have rather harmful consequences, accompanied by a reduction in quality of care, work absentism, lack of commitment to 
organizing, poor drug sales and job dissatisfaction $^{2}$.

Studies on the burnout syndrome among the health workers and health professionals affirm emotional exhaustion as the most significant component of the burnout which is correlated with job absenteeism and thoughts of leaving profession, and that the depersonalization (DP) is closely associated with mistakes in providing care to the health care users ${ }^{3}$.

The first study on the burnout syndrome in pharmacists working in public pharmacies in Serbia was conducted in 2012 on a sample of 647 pharmacists. That study confirmed that close to one half of the participants experienced a high level of burnout $(44.4 \%)^{4}$. High levels of the burnout were more frequent in the mature pharmacists with more extensive length of service ${ }^{4}$. That finding however does not correspond to the results of several other studies, reporting higher levels of burnout in younger pharmacists with shorter work experience, ${ }^{5,6}$ A study on the occupational stress and burnout on a sample of 278 pharmacists working in state- and privatelyowned pharmacies in Serbia concluded that more than a half of the respondents were under stress $(56.1 \%)$, and $34.1 \%$ had symptoms of burnout ${ }^{7}$. However, that study did not include professionals employed in the lines of business related directly to drug manufacturing and marketing.

The aim of this study was to determine factors related to the burnout syndrome in pharmaceutical manufacturing industry and marketing professionals, as well as to analyze the level of the burnout expressed through its three aspects as following: emotional exhaustion, depersonalization and sense of the lack of personal accomplishment.

\section{MATERIALS AND METHODS}

This cross-sectional study was conducted in June of 2016 on a suitable sample of 75 university- educated professionals working in the areas of pharmaceutical manufacturing industry and drug marketing (14 pharmacists working in the manufacturing industry and 61 medical representatives working in marketing on drug promotions in the Belgrade area.

Our sample contained four times more respondents working as medical representatives in the marketing field, than pharmacists employed in the manufacturing industry in positions of authority in the area of control and production of drugs. That ratio reflected a realistic picture of the structure of employees in the pharmaceutical field, where on each highly qualified pharmacists employed in the pharmaceutical manufacturing industry, there were approximately four pharmacists and at least one highly qualified expert (who is not a pharmacist) working in marketing and on drug promotion. Accordingly, in our sample, there was a part of a group of highly educated respondents working in the marketing area, who were not pharmacists, but health workers, chemists and biologists. Regarding the sample size in the survey we decided having the $\alpha$ error level set to 0.05 and $\beta$ error set to 0.10 (meaning the power of the study equaled $1-\beta=$ 0.90 , or $90 \%)^{8}$. Based on the aforementioned parameters, 68 subjects were the minimum calculated sample size.

Of the total of 95 questionnaires that were handed out, 79 were returned (including 4 incompletely filled out questionnaires, which were excluded from the sample). The response rate was $78.95 \%$. The participants who attended postgraduate studies at the University of Belgrade at the Faculty of Pharmacy were surveyed there at the Faculty, while the respondents who were not enrolled in the postgraduate studies were surveyed at their respective workplaces. All respondents were advised that the survey was anonymous and that they by filling out the questionnaire were giving their personal consent to participate in the study. The study was approved by the Teaching and Scientific Council of the University of Belgrade, Faculty of Pharmacy at the 8th Session, on June 9th, 2016.

The instruments used in the study were the Maslach Burnout Inventory - Human Services Survey MBI-HSS (Maslach et al. 1996) ${ }^{9}$, the Rathus Assertiveness Schedule (RAS) ${ }^{10}$ and a general socio-demographic questionnaire. MBIHSS is a self-evaluation questionnaire that is used for determining the presence and extent of the burnout syndrome. It has 22 statements which are scored on a scale from 0 - "never" to 6 - "daily" and it has three subscales that measured perceived emotional exhaustion (the EE scale), depersonalization (the DP scale) and a sense of lack of personal accomplishment (PA scale). The total score could range between 0 and 132. The emotional exhaustion subscale had 9 statements (a score of $\leq 18$ points to a low level of EE, 19 to 26 shows a moderate level, while $\geq 27$ is indicative of a high level of EE). The depersonalization subscale contains 5 statements (a total of $<5$ points to a low-level of DP, 6 to 9 is medium and $\geq 10$ represents a high-level of DP). The lack of sense personal accomplishment subscale had 8 statements (a total of $\geq 40$ stands for a low level 
of the a lack of sense of personal accomplishment, while a score of 34 to 39 shows a moderate level, and a score of $\leq 33$ a high level).

The Rathus Assertiveness Schedule comprises 30 items describing situations typical for assertive behavior ${ }^{11}$. A modified Serbian version of the instrument was used for the purpose of this study ${ }^{12}$. A translation and an adaptation of the original were performed, which included a modification from an original six-point scale to a fivepoint answering scale, according to Likert - from "Strongly disagree" - 1 to "Strongly agree" -5 . The questionnaire has been standardized on cohort of local university-level students ${ }^{12}$.

A general socio-demographic questionnaire, which was created for the purpose of this study, included questions about gender, age, total years of service, years of service in the profession, hours worked per week, line of business, profession, housing type and monthly income.

The statistical analysis was carried out by using the SPSS 20 software package. Pearson's chi-squared test was used, pending the nature of the variables per se, in analyzing the results. The Student's t-test was used on two sets of data in order to compare the average values of parametric characteristics. The Mann-WhitneyU-test was used on independent samples, as an non-parametric alternative, while the Wilcoxon signedrank test was used on dependent samples. Methods of one side parametric correlation and regression were applied in the correlation analysis of the aspects in question, as well as a non-parametric correlation, pending the data distribution. All the applied analytical methods had the statistical significance of 0.05 .

\section{RESULTS}

The study comprised the total of 75 participants of both genders with an average age of $36.7 \pm 8.1$ (minimum 26.0; maximum 58.0; med. 35.0 years of age). The sample consisted of 33 men $(44.0 \%)$ and 42 women $(56.0 \%)$; the difference was not statistically significant $(\chi 2=0.994$; $\mathrm{p}>0.05)$. The average age of female participants was 37.3 (minimum 27.0; maximum 56.0; med. 36.0 years ), while the age of male participants was 35.9 (minimum 26.0; maximum 55.0; med. 35.0 years); the difference was not statistically significant $(\mathrm{t}=0.713 ; \mathrm{p}>0.05)$. The average professional years of service were $9.59 \pm 7.8$, while the workweek averaged $42.8 \pm 6.3$ hours of work.

The analysis showed that there were no statistically relevant differences in the numbers of subjects in the three obtained categories of the EE scale $(\chi 2=1.044 ; \mathrm{p}>0.05)$, where the result was a consequence of approximately equal number of respondents with low (35\%), medium $(29 \%)$ or high $(36 \%)$ scores on the EE subscale. A frequency analysis of the number of subjects in the PA and DP scale categories showed statistically a highly significant difference $(\chi 2=6.714$ and 8.537, respectively, while $\mathrm{p}<0.01$ in both cases). On the PA scale, the subjects with a high level of a lack of personal accomplishment dominated with $53.0 \%, 28.0 \%$ of the subjects reported a medium level, and $19 \%$ a low level of it. On the DP scale, most participants reported a low-level depersonalization (49\%), while $24 \%$ had a medium level and $27 \%$ had a high level.

A statistically significant difference between the values of the DP and Assertiveness scales $(\mathrm{p}<0.01)$ was noted when comparing the average values of numerical properties in comparison with the EE scale item. There weren't any statistically significant differences in the values of other numeric features observed. The highest average DP score values were observed in subjects with the highest EE scale values and then declining eventually to the lowest average (down to one third) in subjects with the lowest scores on the EE scale. The highest average Assertiveness score values were noted in respondents with low level of emotional exhaustion. Statistical significance of the compared numerical features in relation to the EE scale is shown in Table 1.

A comparison of the average values of numerical features in relation to the items of the DP scale, showed that there was a statistically significant difference in the values pertaining to the age of respondents, total years of service, years of service in the profession, of the EE and PA and Assertiveness scales. There was statistically no significant difference recorded concerning the total hours worked per week item. Average values in the age category were highest in respondents with high levels on the DP scale, and the lowest average values in the age category in respondents with medium level DP scale. The highest average values of total length of service and length of service in the profession were noted in respondents with high levels on the DP scale, and in contrast the lowest average value was in the respondents with the medium DP scale. Average values of the EE score were the highest in respondents with high level on the DP scale. The highest average PA score values, were observed in the subjects with low levels on the DP scale, and the lowest average PA values corresponded to the medium values on the DP scale 
(It would be important to note that the scoring on the PA scale was inversely proportional to $\mathrm{EE}$ and DP scales, meaning that high levels of PA scale value indicated the respondent's satisfaction with his/her personal achievements at work, and a low values indicating the opposite). Average score values of assertiveness were the highest in the subjects with low levels on the DP scale and declining to the lowest average values in subjects with the highest level of the DP scale. Statistical significance of the examined numerical characteristics in relation to the DP scale is shown in Table 2.

A comparison of the average values of the numerical properties and the categories of the PA scale showed that there were statistically significant differences in the values of the EE, DP and Assertiveness scales. There was no statistically significant difference in the values of other numeric features noted. The highest average score values of EE were in subjects with high levels of dissatisfaction on the personal achievement scale. The highest DP average score values were highest in respondents with high levels of inefficiency on the PA scale. However, the highest average score values of assertiveness were in subjects with low levels of inefficiency on the PA scale, and then declining to the lowest average values in those with the highest level of inefficiency on the PA scale. Statistical significance of the compared numerical features in reference to a PA scale is shown in Table 3 below.

In our study, a cross-sectional analysis of the Attributable Determinants on the EE scale was performed, which showed statistically significant differences within the line of business in which the subjects were employed $(\chi 2=6.493 ; \mathrm{p}<0.05)$. That may be a consequence of the following findings: pharmacists employed in the field of the pharmaceutical industry (production and control) reported mostly medium and high value levels on the EE scale, as opposed to the medical representatives working in Marketing and Sales (a total of $92.9 \%$ compared to $59.0 \%$ ). Medical representatives employed in the marketing field had far more low-level values on the EE scale than the ones employed in the Manufacturing Industry $(41.0 \%$ vs. $7.1 \%)$. There were statistically significant differences with respect to gender of the respondents $(\chi 2=10.779 ; \mathrm{p}<0.05)$, as a consequence of female respondents displaying high and medium values levels on the $\mathrm{EE}$ scale, in comparison to male respondents (total of $78.6 \%$, as compared to $48.5 \%$ ). Male respondents had two times more low-level scores on the EE scale, comparing to female respon- dents. (51.5\% vs. $21.4 \%)$. There were no statistically significant differences observed in the cross-sectional analysis of the EE scale and the profession of respondents, followed by financial security and residential accommodations. The cross-sectional comparison of the attributes and the EE scale is presented in Table 4.

A cross-sectional analysis of attributes against the DP scale showed a statistically significant difference with respect to the line of work of respondents $(\chi 2=5.393 ; \mathrm{p}<0.05)$. This came as a consequence of the fact that the respondents working in the field of pharmaceutical industry dominated the medium and high-level scores of the DP scale, comparing to the medical representatives (a total of $78.6 \%$, as opposed to $44.3 \%$ ). In medical representatives there were 2.5 times more low-level scores on the DP scale, comparing with participants employed in the pharmaceutical industry $(55.7 \%$ as opposed to $21.4 \%$ ). No statistically significant difference was found when the DP scale was cross-referenced against the participants' gender, profession, or financial security and housing situation. Cross-sectional comparisons of the attributes against the depersonalization scale are shown in Table 5.

A Cross-sectional analysis of attributes and the PA scale ascertained statistically significant differences in regards to the line of business of the respondents $(\chi 2=7.283 ; \mathrm{p}<0.05)$. That was caused by the respondents from the pharmaceutical manufacturing industry, having predominantly medium and high levels of PA scores as compared to the medical representatives (a total of $92.9 \%$ compared to $78.7 \%$ ). On the PA scale, medical representatives had three times higher low-level scores than the respondents employed in the drug manufacturing industry $(21.3 \%$, versus $7.1 \%$ ). There are statistically significant differences with respect to the profession of the respondents $(\chi 2=10.922 ; \mathrm{p}<0.05)$. That derives from the fact that medical doctors display highlevel of burnout on the PA scale, comparing to pharmacists, and dentists. (87.5\%, and down to 48.3 and $20.0 \%$ respectively). The low-level PA score was twice as high in dentists, than in pharmacists and medical doctors $(40.0 \%$ versus $19.0 \%$ and $12.5 \%$ respectively). There were no statistically significant differences in cross-sectional analysis in relation to gender, material and housing provision. The cross-sectional comparison of the attributes on PA scale is shown in Table 6 . 
Table 1. Test results and significance of compared numerical features in relation to the Emotional Exhaustion scale category

\begin{tabular}{|l|c|c|c||}
\hline \hline Parameter & df & F & p \\
\hline \hline Age & 2 & 1.544 & 0.22 \\
\hline Total years of service & 2 & 1.945 & 0.15 \\
\hline Years of service in the profesion & 2 & 2.314 & 0.106 \\
\hline Hours worked per week & 2 & 0.276 & 0.759 \\
\hline Personal accomplishment & 2 & 0.932 & 0.399 \\
\hline Depersonalization & 2 & 27.465 & $0.000^{* *}$ \\
\hline Assertiveness & 2 & 6.272 & $0.003^{* *}$ \\
\hline
\end{tabular}

Table 2. Test results and significance of compared numerical features in relation to the categories on the Depersonalization scale

\begin{tabular}{||l|l|l|l||}
\hline Parameter & df & F & p \\
\hline \hline Age & 2 & 5.935 & $0.004^{* *}$ \\
\hline Total years of service & 2 & 5.057 & $0.009^{* *}$ \\
\hline Years of service in the profession & 2 & 5.584 & $0.006^{* *}$ \\
\hline Hours worked per week & 2 & 0.303 & 0.739 \\
\hline Emotional exhaustion & 2 & 26.612 & $0.000^{* *}$ \\
\hline Personal accomplishment & 2 & 2.591 & $0.048^{*}$ \\
\hline Assertiveness & 2 & 5.872 & $0.004^{* *}$ \\
\hline
\end{tabular}

Table 3. Test results and significance of compared numerical features in relation to categories on the Personal Accomplishment scale scale

\begin{tabular}{||l|l|l|l||}
\hline Parameter & df & F & p \\
\hline \hline Age & 2 & 0.289 & 0.750 \\
\hline Total years of service & 2 & 0.356 & 0.702 \\
\hline Years of service in the profession & 2 & 0.271 & 0.764 \\
\hline Hours worked per week & 2 & 1.723 & 0.186 \\
\hline Emotional exhaustion & 2 & 5.253 & $0.007^{* *}$ \\
\hline Depersonalization & 2 & 3.651 & $0.031^{*}$ \\
\hline Assertiveness & 2 & 7.484 & $0.001^{* *}$ \\
\hline
\end{tabular}

Table 4. A cross-sectional comparison of the investigated attributeson the Emotional Exhaustion scale

\begin{tabular}{|c|c|c|c|c|c|c|c|}
\hline & \multirow{3}{*}{ Attributes } & \multicolumn{6}{|c|}{ Emotional exhaustion } \\
\hline & & \multicolumn{2}{|c|}{ Low level } & \multicolumn{2}{|c|}{ Medium level } & \multicolumn{2}{|c|}{ High level } \\
\hline & & n & $\%$ & $\mathbf{n}$ & $\%$ & $\mathbf{n}$ & $\%$ \\
\hline \multirow{2}{*}{ Line of business } & "Industrial manufacturing & 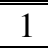 & 7.1 & 7 & 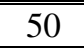 & 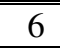 & 42.9 \\
\hline & Drug marketing & 25 & 41 & 15 & 24.6 & 21 & 34.4 \\
\hline \multirow{2}{*}{ Gender } & Male & 17 & 51.5 & 4 & 12.1 & 12 & 36.4 \\
\hline & Female & 9 & 21.4 & 18 & 42.9 & 15 & 35.7 \\
\hline \multirow{4}{*}{ Profession } & Pharmacist & 18 & 31 & 17 & 29.3 & 23 & 39.7 \\
\hline & Dentist & 2 & 40 & 2 & 40 & 1 & 20 \\
\hline & Medical doctor & 4 & 50 & 2 & 25 & 2 & 25 \\
\hline & Other (biologist, chemist) & 2 & 50 & 1 & 25 & 1 & 25 \\
\hline \multirow{3}{*}{$\begin{array}{l}\text { Housing } \\
\text { type }\end{array}$} & I own an apartment & 17 & 32.7 & 14 & 26.9 & 21 & 40.4 \\
\hline & I live with parents & 7 & 43.8 & 5 & 31.2 & 4 & 25 \\
\hline & I rent & 2 & 28.6 & 3 & 42.9 & 2 & 28.6 \\
\hline \multirow{3}{*}{$\begin{array}{l}\text { Financial } \\
\text { security } \\
\text { (monthly needs) }\end{array}$} & Income below needs & 5 & 41.7 & 2 & 16.7 & 5 & 41.7 \\
\hline & Income sufficient & 15 & 30 & 17 & 34 & 18 & 36 \\
\hline & Income exceeds the needs & 6 & 46.2 & 3 & 23.1 & 4 & 30.8 \\
\hline
\end{tabular}


Table 5. A cross-sectional comparison of the analyzed attributes on the Depersonalization scale

\begin{tabular}{|c|c|c|c|c|c|c|c|}
\hline & \multirow{3}{*}{ Attributes } & \multicolumn{6}{|c|}{ Depersonalization } \\
\hline & & \multicolumn{2}{|c|}{ Low level } & \multicolumn{2}{|c|}{ Medium level } & \multicolumn{2}{|c|}{ High level } \\
\hline & & $\bar{n}$ & $\%$ & $\mathbf{n}$ & $\%$ & $\mathrm{n}$ & $\%$ \\
\hline \multirow{2}{*}{ Line of business } & Drug manufacturing industry & 3 & 21.4 & 5 & 35.7 & 6 & 42.9 \\
\hline & Drug marketing & 34 & 55.7 & 13 & 21.3 & 14 & 23.0 \\
\hline \multirow{2}{*}{ Gender } & Male & 18 & 54.5 & 6 & 18.2 & 9 & 27.3 \\
\hline & Female & 19 & 45.2 & 12 & 28.6 & 11 & 26.2 \\
\hline \multirow{4}{*}{ Profession } & Pharmacist & 26 & 44.8 & 14 & 24.1 & 18 & 31.0 \\
\hline & Dentist & 4 & 80.0 & 0 & 0.0 & 1 & 20.0 \\
\hline & Medical doctor & 4 & 50.0 & 3 & 37.5 & 1 & 12.5 \\
\hline & Other (biologist, chemist) & 3 & 75.0 & 1 & 25.0 & 0 & 0.0 \\
\hline \multirow{3}{*}{$\begin{array}{l}\text { Housing } \\
\text { type }\end{array}$} & I own an apartment & 25 & 48.1 & 10 & 19.2 & 17 & 32.7 \\
\hline & I live with parents & 9 & 56.2 & 6 & 37.5 & 1 & 6.2 \\
\hline & I rent & 3 & 42.9 & 2 & 28.6 & 2 & 28.6 \\
\hline \multirow{3}{*}{$\begin{array}{l}\text { Financial } \\
\text { security } \\
\text { (monthly needs) }\end{array}$} & Income below needs & 5 & 41.7 & 3 & 25.0 & 4 & 33.3 \\
\hline & Income sufficient & 26 & 52.0 & 11 & 22.0 & 13 & 26.0 \\
\hline & Income exceeds the needs & 6 & 46.2 & 4 & 30.8 & 3 & 23.1 \\
\hline
\end{tabular}

Table 5. A cross-sectional review of the attributes on the Personal Accomplishment scale

\begin{tabular}{|c|c|c|c|c|c|c|c|}
\hline & \multirow{3}{*}{ Attributes } & \multicolumn{6}{|c|}{ Personal accomplishment } \\
\hline & & \multicolumn{2}{|c|}{ Low level } & \multicolumn{2}{|c|}{ Medium level } & \multicolumn{2}{|c|}{ High level } \\
\hline & & $\mathbf{n}$ & $\%$ & $\mathbf{n}$ & $\%$ & $\mathbf{n}$ & $\%$ \\
\hline \multirow{2}{*}{ Line of business } & Drug manufacturing industry & 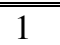 & 7.1 & 1 & 7.1 & 12 & 5.7 \\
\hline & Marketing & 13 & 21.3 & 20 & 32.8 & 28 & 5.9 \\
\hline \multirow{2}{*}{ Gender } & Male & 9 & 27.3 & 6 & 18.2 & 18 & 4.5 \\
\hline & Female & 5 & 11.9 & 15 & 35.7 & 22 & 2.4 \\
\hline \multirow{4}{*}{ Profession } & Pharmacist & 11 & 19.0 & 19 & 32.8 & 28 & 8.3 \\
\hline & Dentist & 2 & 40.0 & 2 & 40.0 & 1 & 0.0 \\
\hline & Medical doctor & 1 & 12.5 & 0 & 0.0 & 7 & 7.5 \\
\hline & Other (biologist, chemist) & 0 & 0.0 & 0 & 0.0 & 4 & 0.0 \\
\hline \multirow{3}{*}{$\begin{array}{l}\text { Housing } \\
\text { type }\end{array}$} & I own an apartment & 9 & 17.3 & 11 & 21.2 & 32 & 1.5 \\
\hline & I live with parents & 4 & 25.0 & 7 & 43.8 & 5 & 1.2 \\
\hline & I rent & 1 & 14.3 & 3 & 42.9 & 3 & 2.9 \\
\hline \multirow{3}{*}{$\begin{array}{l}\text { Financial } \\
\text { security } \\
\text { (monthly needs) }\end{array}$} & Income below needs & 3 & 25.0 & 3 & 25.0 & 6 & 0.0 \\
\hline & Income sufficient & 8 & 16.0 & 15 & 30.0 & 27 & 4.0 \\
\hline & Income exceeds the needs & 3 & 23.1 & 3 & 23.1 & 7 & 3.8 \\
\hline
\end{tabular}

\section{DISCUSSION}

The results of our study present the burnout syndrome and associated factors, being an important issue among the professionals working in the fields of the pharmaceutical manufacturing industry and marketing. In this study, we compared the results of our study with preceding studies, researching the burnout syndrome among pharmacists and other health professionals in Turkey, South Africa, the United States, Japan, Australia, Northern Ireland, Nigeria and the Republic of Serbia.

An analysis of the results of our study showed a high level of burnout in $36 \%$ on the Emotional Exhaustion scale, among the professionals employed in the pharmaceutical manufacturing industry and marketing in Serbia. Our result values were significantly higher than the results obtained in Turkey, where the same questionnaire was used on 251 pharmacists from the Chamber of Pharmacists Association in Ankara, with $1.2 \%$ of subjects reporting a high level of emotional exhaustion ${ }^{13}$. Low levels of emotional exhaustion were reported by $35 \%$ of the respondents in our study, which points to a much lesser percentage of the low-level values, if compared to pharmacists from South Africa, with $62 \%$ reporting low levels ${ }^{14}$. On the Depersonalization Scale, which assessed insensitive and impersonal attitude towards the customers (indifferent, careless, emotionless and negative attitude towards the service users and colleagues), one half of the respondents, who are employed in the area of pharmaceutical manufacturing industry and marketing, were in the range of high and medium levels of depersonalization. The high level of depersonalization was reported by $27 \%$ 
of the respondents, which was over three times more than among the pharmacists in Ankara where $8 \%$ of the subjects manifested high-level scores on the aforementioned scale ${ }^{13}$. In addition, our results are not consistent with previous studies conducted in the US that reported moderate levels of burnout among the pharmacists ${ }^{15,16}$. In the sample of the pharmacists from Japan, 49.2\% of respondents were at high risk for developing the burnout. All that indicates the significance of cultural differences ${ }^{1}$.

The PA scale that examines a perceived competence, success and personal accomplishment in work environment showed that $53 \%$ of the respondents in our study had high levels of perceived lack of personal accomplishment. Pharmacists who have low levels of the sense of personal accomplishment may display less initiative and creativity at work, which in turn causes lower productivity and poor performance at work $^{6}$. The results of our study are nearly similar to those obtained in the study of the burnout syndrome carried out in 2005 on hospital pharmacists in Australia, where 39\% of respondents had high EE scores, 49\% had high PA scores, while the majority of pharmacists had low scores on the depersonalization scale $(60 \%)^{5}$. By comparing high scores of the EE, DP and PA scales, we may notice that most participants exhibit the highest levels of burnout on the PA scale. We may link this finding to the years of service in the profession, considering that more than half of the professional working in the pharmaceutical manufacturing industry and marketing have less than nine years of professional experience. For that reason, their sense of competence at work may be lower, considering that the competence is achieved through developing one's own individual competences, knowledge and skills, leading eventually to more successful performance results ${ }^{17}$.

Further analysis of the results of our research demonstrated that the average assertiveness scores were the highest in those who had lowlevel emotional exhaustion, depersonalization and perceived professional inefficiency, while the lowest average assertiveness scores were found in the respondents who reported the highest levels of burnout on the said subscales. This finding confirmed that the participants who were assertive and possessed the skills for clear and efficient communication with others were at lower risk of developing the burnout syndrome ${ }^{18}$. The significance of the using the appropriate communication in the pharmaceutical practice and its influence on the quality of the transfer of information and giving advice between the patients and the health care workers has been recognized in numerous studies in that area ${ }^{1,19}$.

The comparison of frequency and severity of the burnout syndrome per each subscale (EE, DP and PA) against the line of business of the participants showed statistically significant differences between low, medium and high levels of the burnout. Among medical representatives, who worked in the drug marketing area there were almost 6 times more low-level scores on the emotional exhaustion scale, 2.5 times more lowlevel scores on the depersonalization scale and 3 times more low-level scores on the lack of personal accomplishment scale, as compared to the pharmacists who worked in the industrial manufacturing area. Having in mind, that the most significant differences were identified on the EE scale, and also that the earlier studies had confirmed that the most stressful aspects of work were closely related to that stage of development of the burnout syndrome ${ }^{20,21}$, it would be important to examine the differences between the pharmacists in the marketing and the industrial manufacturing areas when it comes to their workload (primary predictor of emotional exhaustion $^{22}$ ), job requirements, availability of organizational support and potentials for professional and career advancement ${ }^{23}$. This finding of our study is in accordance with the studies of the burnout syndrome among pharmacists in the Northern Ireland, which confirmed the line of business within the pharmaceutical profession to be a significant factor, influencing the differences in the intensity of the burnout syndrome ${ }^{23}$.

Comparison of average age of our respondents, their total years of service and years of service in the profession and the DP scale yielded a statistically significant difference. Most of the senior respondents, working in the pharmaceutical industrial manufacturing and marketing, and having longer total years of service and years of service in the profession scored predominantly in the high ranges on the depersonalization scale. The current situation in the field of pharmacy in Serbia is in accordance with this finding. Over the last two decades, professional expectations and responsibilities in the pharmaceutical practice have drastically increased, particularly on the primary healthcare level. The introduction and use of electronic recordkeeping systems requires new knowledge and skills. Frequent changes in the legislation and the requirements that are reflected upon the pharmacists, particularly on those who work in the public sector, add pressure when it comes to 
working with clients. It has not been sufficiently investigated how willing the senior employees are to adequately respond to such changes and to maintain their professional competences accordingly ${ }^{4}$. Any changes and improvements aimed at developing the business activity may want to include the wellbeing of those who perform such activity and who are the first ones to experience the consequences of the changes. If stress in the pharmaceutical profession is not recognized and reduced, the consequences will reflect upon, not only the pharmacists, but on those who use their services as well ${ }^{23,24}$. The first step towards operational improvements and greater wellbeing of the pharmaceutical professionals is the early detection of factors which contribute to the development of the burnout syndrome in pharmacists $^{25}$, as well as implementing adequate measures of prevention.

The comparison of scores on EE subscale against the gender of our respondents showed that male respondents working in the pharmaceutical industrial manufacturing and marketing had 2 times more low-level scores on the emotional exhaustion scale in regard to the females. The fact that female respondents predominantly displayed medium and high scores on the emotional exhaustion scale was consistent with some of the earlier studies ${ }^{26}$. That may be linked to female respondents experiencing a deeper emotional involvement in the difficulties, regarding clients, coworkers and the work process itself ${ }^{27}$.

Concerning the participants' profession, the only statistically significant difference was recorded on the PA subscale which measured a lack of personal accomplishment. Medical representatives who were medical doctors, had many more scores indicative of high levels of the lack of personal accomplishment (87.5\%), in comparison to pharmacists (48.3\%) and dentists (20.0\%). An explanation for such differences in personal accomplishment scores requires assessing the attitudes of medical doctors and dentists regarding the reputation of their primary professions with the respect to the position of a medical representative, since the job as a medical representative working in marketing and drug promotions is not their primary professional vocation.

This study is the first one examining a phenomenon of the burnout syndrome in the pharmaceutical manufacturing industry and marketing in Serbia, however, we should mention some limitations which the study had. The information on independent and dependent variables was obtained by means of self-evaluation tests, without observing the behavior. The sample was small and it included participants from Belgrade only, it was not homogenous in terms of the participants' line of business and their profession (in addition to pharmacists, we had medical doctors, dentists, chemists and biologists working as medical representatives in the sector of pharmaceutical marketing). However, in spite of the limitations, the results are significant, as they revealed that communication skills, i.e. assertiveness correlated with three main dimensions of the burnout syndrome (emotional exhaustion $\mathrm{p}=0.003$, depersonalization $\mathrm{p}=0.004$ and lack of personal accomplishment $\mathrm{p}=0.001$ ). In this study, lower levels of assertiveness pointed out to a more severe burnout syndrome, so our results highlight the importance of the training in assertive communication skills as one of the steps for preventing the development of the burnout syndrome. Equally important is that the correlation of particular socio-demographic features of respondents with the main dimensions of the burnout syndrome may help single out risk groups.

\section{CONCLUSION}

The presence of the burnout syndrome among the employees in the areas of pharmaceutical manufacturing industry and marketing has been confirmed. According to our research, the following key factors associated with the burnout syndrome stand out: gender, age, total years of service, years of service in the profession, line of business, profession and the level of assertiveness. The number of male respondents who display the low-level ranges of emotional exhaustion is two times higher, compared to the number of female respondents. The more senior respondents are (and with more years of service), the greater tendency to develop depersonalization they demonstrate. Pharmacists working in the industrial manufacturing area have been found to experience significantly more medium and high-level burnout with respect to the ones working in marketing. Medical doctors who worked as medical representatives displayed significantly higher levels of the lack of personal accomplishment, as compared to the their fellow pharmacists, dentists and other highly educated professionals. The more assertive participants were, the lower levels of emotional exhaustion, depersonalization and perceived inefficiency at work they displayed.

\section{ACKNOWLEDGEMENTS}

This study was carried out as a part of the larger project of scientific research funded by the 
Serbian Ministry of Education, Science and Technological Development (Project No. 41004).

\section{REFERENCES}

1. Higuchi $\mathrm{Y}$, Inagaki $\mathrm{M}$, Koyama $\mathrm{T}$, et al. . A crosssectional study of psychological distress, burnout, and the associated risk factors in hospital pharmacists in Japan. BMC Public Health 2016 Preuzeto sa: https://bmcpublichealth.biomedcentral.com/articles/10. 1186/s12889-016-3208-5

2. Rothmann S, Malan AM , Rothmann JC . Sense of coherence, coping and burnout in a corporate pharmacy group. 7th Annual PsySSA Conference; Johannesburg, 13-17 August 2001. Preuzeto sa: http://citeseerx.ist. psu.edu/viewdoc/download?doi=10.1.1.202.7936\&rep $=$ rep $1 \&$ type $=$ pdf

3. Suner-Soler R, Grau-Martín A, Flichtentrei D, et al. . The consequences of burnout syndrome among healthcare professionals in Spain and Spanish speaking Latin American countries. Burnout Research 2014;1(2):82-9.

4. Jocic DD , Krajnovic MD . State anxiety, stress and burnout syndrome among community pharmacists: relation with pharmacists attitudes and beliefs. Indian journal of pharmaceutical education 2014;48(2): 9-15.

5. Muir PR, Bortoletto DA . Burnout among Australian hospital pharmacists. Journal of Pharmacy Practice and Research 2007;37(3): 187-9.

6. Rothmann S, Scholtz PE, Rothmann JC, Fourie C . The relationship between individual variables and work-related outcome. International Council for Small Business 47th World Conference papers. San Juan, Puerto Rico; 2002.

7. Jocic D, Krajnovic D, Lakic D, Tasic L . Occupational stress and burnout: impact on the attitudes of pharmacists in providing pharmaceutical services. Value in Health 2012; 15(7): 543.

8. Erić-Marinković J, Dotlić R, Janošević S, Kocev N, Gajić M , Ille T . Statistika za istraživače u oblasti medicinskih nauka. Beograd. Medicinski fakultet Univerziteta u Beogradu. 2006.

9. Maslach C, Jackson SE, Leiter MP . Maslach burnout inventory: Manual. Palo Alto, Consulting Psychologists Press, California. 1996.

10. Rathus SA . A 30-item Schedule for Assessing Assertive Behavior. Behav Ther 1973;4: 398-406.

11. Košutić Ž , Dukanac V , Bradić B , et al . Asertivnosti kod adolescenata sa anksioznim poremećajima, povezanost sa dimenzijama ličnosti, socijalnom zrelošću i sociodemografskim karakteristikama. Psihijatrija danas 2012; 44(1): 47-59.

12. Milankov R . Standardizacija Ratusovog upitnika za merenje asertivnosti (RAS), diplomski rad. Filozofski fakultet, Univerzitet Novi Sad. 1993.

13. Calgan Z, Aslan D, Yegenoglu S . Community pharmacists burnout levels and related factors: an example from Turkey. Int J Clin Pharm 2011; 33: 92-100.

14. Rothmann S, Rothmann JC, Bornman S, Basson WD Burnout of pharmacists and pharmacist"s assistants: is it a reality?. Pharmaciae 2001; 9(3): 24-6.

15. Gupchup GV, Singhal PK, Dole EJ, Lively BT. Burnout in a sample of HMO pharmacists using the
Maslach burnout inventory. Journal of Managed Care Specialty Pharmacy 1998; 4(5): 495-503.

16. Lahoz MR, Mason HL . Burnout among pharmacists. American pharmacy 1990;NS30(8):28-32.

17. Vujić D. Kompetencije-odgovor na nove izazove upravljanja ljudskim resursima. Druga međunarodna naučna konferencija pod nazivom Synthesis; Univerzitet Singidunum u Beogradu, 16-17 april. 2015 Preuzeto sa: http://jiws.rs/wpcontent/uploads/2016/03/TEKST-SYNTEZISPREMA-UPUTSTVU-k.pdf

18. Popov S, Latovljev M, Nedić A. Sindrom izgaranja kod zdravstvenih i prosvetnih radnika: Uloga situacionih i individualnih faktora. Psihološka istraživanja 2015; 18(1): 8-15.

19. Wallman A, Vaudan C, Kälvemark Sporrong S . Communications Training in Pharmacy Education, 1995-2010. American Journal of Pharmaceutical Education 2013; 77(2): 36.

20. Eslami A, Kouti L, Javadi M, Assarian M, Eslami K. An investigation of job stress and job burnout in Iranian clinical pharmacist. Journal of Pharmaceutical Care 2015; 3(1-2): 23.

21. Rothmann S, Malan AM . Work-related well-being of South African hospital pharmacists. Sauth African Journal of Industrial Psychology 2011;37(1) Preuzeto sa: http://www.sajip.co.za/index.php/sajip/article view/895/1041

22. Janssen PM, Schaufeli WB, Houkes I. Work-related and individual determinants of the three burnout dimensions. Work and Stress 1999;13:74-86.

23. McCann L, Hughes CM, Adair CG, Cardwell C. Assessing job satisfaction and stress among pharmacists in Northern Ireland. Pharmacy World \& science 2009; 31(2): 188-94.

24. Suleiman AK. Stress and job satisfaction among pharmacists in Riyadh, Saudi Arabia. Saudi Journal of Medicine \& Medical Sciences 2015; 3(3): 213-19.

25. Malan AM. Burnout and engagement of hospital pharmacists in South Africa, unpublished doctoral thesis. North-West University, Potchefstroom. 2005. Preuzeto sa: http: //malan_agatham\%20(3).pdf

26. Olanrewaju AS, Chineye OJ. Gender differences in burnout among health workers in the Ekiti State University Teaching Hospital Ado-Ekiti. International Journal of Social and Behavioural Sciences 2013; 1(6): 112-21.

27. Petrović N, Maćešić-Petrović D, Đorđević M. Sindrom sagorevanja kod profesionalaca koji rade u zatvorskom tretmanu maloletnih delikvenata. Socijalna misao 2010; 2: 50-69.

28. Jeđuć I. Alisa u zemljičuda -kvalitativnametodologija I metodautemeljeneteorije. Hrvatska revija za rehabilitacijska istraživanja 2007; 43(2): 83-101.

29. Mollerup A, Johansen JD, Thing LF. Knowledge, attitudes and behaviour in everyday life with chronic hand eczema: A qualitative study. Br J Dermatol. 2013; 169(5): 1056-65.

30. Magin P, Adams J, Heading G, Pond D. 'Perfect skin', the media and patients with skin disease: A qualitative study of patients with acne, psoriasis andatopic eczema. Aust J Prim Health. 2011; 17(2): 181-5. 